\title{
Denial of the Author's Horizon in the Book "The Winter of Great Lonliness"
}

\author{
Muhamed Dervishi \\ Universiteti "Aleksandër Moisiu”, Durrës
}

\author{
Doi:10.5901/ajis.2013.v2n8p451
}

\begin{abstract}
"The Winter ..." is a polyphonic novel. A crucial importance in the polyphonic text plays the relationship between the horizon and the character and the one of the author. According to the researcher Mikhail Bakhtin, the author as the carrier of his own idea enters as an orientation among the other orientations in the polyphonic novel. Meanwhile, according to N.F.Alapat, the characters in the novel have maximum freedom, which allows them not only to discuss with each other, but even to the author himself. This means that the author in the polyphonic novel enters with his horizon orientation among the other orientations. In this regard for it is of interest for the polyphonic text to investigate even the relationship of the author's horizon with that of the character in the book "The Winter ..." by Kadare in this regard questions which would need answer would be: 1. In the book "The Winter ..." do we have an author who enters with his orientation as a horizon among the other horizons? 2. If not, then, if the author is only attracted to his creative scheme, which is the stylistic solution of Kadare's in the relations between the author and the character's horizon. By answering these questions first of all, it would emerge the individuality of Kadare in the polyphonic text typology, and secondly, if there is something particular, where and how it is incarnated in the stylistic choices in the book "The Winter ..."
\end{abstract}

Keywords: polyphonic, author / character's horizon /, individuality, stylistic solutions

In the polyphonic novel, the author, according to Bachtin, "is not required to renounce himself and his conscience" and that "the author as the carrier of his own idea must enter as an orientation among the other orientations" (Bachtin M. 1968) Meanwhile, according to N.F.Alapat, in his paper on the Joice's polyphony, in the polyphonic novel "characters have maximum freedom, allowing them to discuss with each other and even with the author himself" (Alapatt NF 2002). Which implies the same thing, that the author in the polyphonic novel is an orientation among other orientations. In our case, the question about the book "The winter ..." is: do we have in this work the author as "an orientation among the other orientations" and, if so, do we have characters that discuss even "with the author himself"? What do we find, in the text which deals with the relationship between the author and the character's horizon? In the case of Dostoevsky, even though the author is "orientation among the other orientations", the sovereignty of the character, his autonomy, implies the violation of the author's horizon. Here's what does Bakhtin say about this: "the opportunity of the Dostoevsky's character is the opportunity to express through the words his inner self in all its purity, but to listen and show, to be involved in another person's horizon, the laws of the horizon should be violated, because a normal horizon contains the figure of another man, and not a different horizon in its completeness "(Bachtin M, 1968).

Since this is a crucial point in determining the character of polyphonic in "The Winter ...", but it is as well as in the prose of Kadare, researching further. Of course, what interest us are not the stylistic choices of Dostoevsky. Here's what for example says Bakhtin about Tolstoy's prose: "Tolstoy's world is monolithically monological; the character's word is closed under the strictness of the author's words. In the word wrapping of the other (the author) it is given even the last word of the character, the hero's consciousness is only one point of his punctual image, and awareness, in essence, is determined by this figure even where, from the thematic perspective, the conscience goes through a crisis and a radical inner transformation "(Bachtin M 1968).

While in Dostoevsky's book: "the author's words oppose the words of the character, which is completely valid and absolutely free of mixtures. It is precisely where the problem arises, the use of the author's word, the problem of his formal and artistic position against the character's word. This problem is deeper than the matters belonging to the author's word as a surface component element or a surface replacement with the Icherzablung form, which are carried out by the narrator's interference, by constructing scenes of the novel and by the author's word reduction in the level of a simple recorder. All these combined methods of disappearance or weakening of the author's word, taken by itself, still does not affect the essence of the problem "(Bachtin M, 1968). Following: " The consciousness as the dominant artistic figure in building the character's figure it also implies a fundamentally new position of the author against the figure 
presented" (Bachtin M, 1968).

Exactly here lies the essence. So, do we have in "The Winter ...", a radically new position? If so, how will it be proved in the relations between the author and the character's horizon? Secondly, do we have to do with methods of reducing or weakening the author's word that does not "affect the essence of the problem"? And further: do we have an author who opposes the character's word, but that the latter is "absolutely free of mixtures" as in Dostoevsky? Or, beyond that, in the line of the polyphonic novel, we do have an "invisible" author, otherwise, the lack of the author as an "orientation among the other directions." If we have to do with the latter case, i.e. the invisible author, it is obvious that it would be a new position of the author in relation to the polyphonic text, as we always have the author as an orientation or the character who discusses "even with the author ".

In Kadare's prose and in the book "The Winter ... the character's perceptions $(P)$ is designed from the bottom up. So after two or three sentences the character appears to prove, that the above sequences come from his perception and not from the author. Let's see now whether we are dealing with a stylistic feature that characterizes the entire text. Secondly, we will see what happens with the author's horizon, if we do have a technical violation of the author's horizon or, even more the "disappearance" of the author's horizon. To make this clear we will analyze a few paragraphs from chapter IV:

(The light) "It flowed continuously. It dawn in glass windows, covering everything. You had no place where to hide from it. It would find you where ever you would be under the sheets, under the eaves. / Mira (P1 /horizon projection of the character from the bottom up, in the three previous sentences), tried to hide her face under the pillow, but it was not possible. The morning light poured into the room over and over again. Last shadows of sleep, some figures and grotesque humans, shaky, weakened by lighting, were losing their voices, became dumb even with their movements, as in a double recording, now strange voices and noises were ascending. Mira woke up (P2). She (P3), failed to understand what Altin had said earlier. He talked and talked, but the exterminating light constantly fell on his shoulder, melted him, made him more transparent, until in the end it turned him into wind in front of her eyes "( Kadare I.1973).

This is a paragraph, first paragraph, but we have two sequences that disrupt in P1/P2. In the first sequence we have Mira in bed, on awakening, under the effect of light. But the author does not objectify her or her environment, windows, curtains, sun, rays, etc., etc... We have no author's point of view, which would imply even the "author's" horizon. All the feelings and senses belong to Mira. So the whole perception comes from her, the character. While the scene that would respond to this perception, its objectification in a full frame, which means a girl who is awoken by the effect of light, it is not built by the "author" but by the reader. Second, climax is noted, increased semantic intensity, as well as rhythmic segmentation of sentences: "flowed / dawned in glass windows / covering everything / You had no place where to hide from it / it would find you anywhere", etc...In this case, the function of words used in a set of adhesive semantic sequence or repeated anadiplosis, is played by the verbs, headed by the first verb: flow. Then we have: dawn etc... So the intensity of perception corresponds with the climax. However once again we have the character proved and not the "author" in the text. Here we have no monological text proceedings which would weaken the author's horizon; also there are no violations of the author's horizon, as in Dostoevsky. P1 in this case is in the function of the "disappearance of the author's horizon." So, in this sequence laspect we have the character that projects herself from the bottom and up. The "Author" does not exist in any corner of this framework, unless the character appears in P1/P2 / etc.

From the perspective of the "Susrafce" exit, so the exit "to reality" (S), (the effect of the morning light on Mira), this exit is confirmed, somehow it is an exit which is done from / through intrasubjective (Intr) perspective, it comes out through Mira's horizon. Here we do not have an "author" or his horizon.

Meanwhile, P1: "Mira tried once again to hide her face under the pillow", etc., is the author's horizon, so it is the author who appears in P1 "in reality". But, as we saw, this sentence, apart from the function of introducing the author's horizon, it also performs the function of exit from the author's horizon in the four previous sentences, so for all the previous sequence. In the other sequence: "the last shadows of sleep" ... as the author's horizon appeared in the previous sentence P1, there's an opportunity for the author "to move up" and see everything from his horizon.

However, even in this sequence, which is in the sentence, we always have Intr, so intrasubjectivity. Even here, as above, we have the same climax, growing semantic intensification. Immediately after the climax, we have P2: "Mira woke up." This sentence, does not only brings the author's horizon, but also serves to eliminate any misunderstanding between him and the reader for the climax sequence that comes from Intr, before it, so before the author's horizon. The third sequence (P3-only "that"), which comes immediately after the author's horizon, the whole one is in Intr. Mira has in her consciousness a dream with Altin, "he spoke and spoke", etc... But here again we do not have an author, the horizon is totally for the character. There is no "objectivity" what would have meant the author's horizon, the dialogue of Mira with 
Altin in a dream before she woke up, etc., however, the word "dream" never appears.

The framework therefore comes from the character, from Intr while the exit "to reality" of this framework, as in the first sequence is done by the reader. And precisely in this technique, the disappointment of the readers with the author's horizon in this game of horizons, lays the stylistic essence of the suggestive effect in Kadare's prose. Further, in this sequence we have again the climax, which proves not only the return to the Intr, but also the stylistic unit of the text.

Let's see what happens with the sequences of the second paragraph:

\begin{abstract}
"After all those rainy days, behind the glass it was a clear day. Some light noises were coming from the kitchen. The aunt's bed was empty. (P1): Mira stretched two or three times in bed, then gazed at the ceiling and stood still. (Author's horizon P1 apart from leading us to $S$ / it also has the function to be projected from above, to show us that standpoint from the above sequence comes from the character's horizon. Besides other things we have: "The aunt's bed was empty", i.e. it is Mira's horizon, rather than of the author, in which we would have: Rabo. Altin will repent. (Note the lack of the exclamation mark, therefore we are always in Intr through / from Mira's Intr). This was the only thought that came to her made. (P2, in the same function). Two days ago, Altin without any reason, had insulted her during the long break and she did not speak to him anymore. Altin used to be very nervous in her presence. Maybe he's psycho, Mira said to herself (P3), and, when she returned sideway put her head in her right palm and was looking from the window. (P4 in the same function). From the kitchen and the hallway known morning noises kept coming: the cracking of chairs, steps, the buzz of the electric shaving machine of Besnik" (Kadare I. 1973). (So, from the viewpoint of the character's horizon, Mira).
\end{abstract}

Let's see what happens in the next paragraph:

"Mira took a deep breath, hung out her feet of the bed and was about to stand up, but at the last minute she stayed. Fasten her knees with her hands, staring at the window. Then moved aside the nightgown a little bit and looked at one of her shoulder. Moved it a bit more. Her shoulder looked beautiful. Her night shirt was long. She raised it and looked at her feet. She should not gain more weight "(Kadare I. 1973).

In this sequence we are in S, "in reality", through the author's horizon. The sentences in italics come from the Intr that means from the character's horizon. There appear no more the stilemes: Mira thought, she said to herself, etc... In this sequence the author's horizon sequence appears at the top of the paragraph, but he aims at the character's horizon, and when the conditions are appropriate for this he just enters the Intr and the appearance comes from the character's horizon. It happens the same in the following paragraph:

"Suddenly jumped at her feet full of joy and, jumping through the hallway, entered into the toilet.

- Hold on a second-Mira, - said Besnik without turning his head from the mirror.

-Why don't you shave in your room? - She said.

- Look, I finished". (Kadare I. 1973).

Here we are in reality, but it is aimed character's horizon ("without turning his head from the mirror, so how Mira sees it). Meanwhile, this dialogue happens in reality, and meanwhile performs its function, creates the conditions for the transition to the character's Intrasubjectivity).

Here's what we have below:

"Her maroon eyes, soft and a little tailed, which gave her look a tinge of pleasant cunning, especially when they looked sideways, appeared in the mirror next to the face of Besnik, which had an unnatural strain, as the face of any man who is shaving himself. (All this sequence comes from Intr, it is a narcissistic female gameM.D.). She showed her tongue to her brother and then began to hit him at his back with her fist "(Kadare l.1973).

Here below, again we have a dialogue, which performs the same function, a transition of the character in Intr, so in his horizon:

(P1): "When Mira went into the kitchen, her father and her aunt were silent sitting on the sofa. Her father was pale in the face. It was obvious that he has had problems with his health again. Besnik was talking to a doctor on the phone. The father needed another check-up "(Kadare I. 1973).

The words in italics are in the Interindividuality,/Intersubjectivity: Mira-her father. But in this case we lack stilemes like: Mira thought, to her the father seemed pale etc.., etc... And in the sentence "Besniku was talking" etc., author's stilemes were missing, and this is what it would be normal in monological text: Mira turned her head and saw Besnik etc... 
So, we have another case where the author's horizon creates conditions for the destruction of the author's horizon within a sequence.

The text proceeds in the same way in the three other paragraphs. The author goes "to reality" or passes in $\mathrm{P}$ only to the extent that he needs to eradicate his horizon. Now let's see how the author comes out from a character's horizon to enter a different character's horizon. We are in the last paragraph of Mira's horizon. And here's what we have:

\begin{abstract}
"After twenty minutes Besnik and the father left. (So we are in "reality", regarding Mira's horizon: the father, not Struga, what would have been from the author's horizon). Ben went to the kitchen (always from Mira's horizon, is the character who sees, not the author). - Why didn't you ask where did they go? - said angrily her aunt. (Always Mira's horizon: aunt). Ben didn't know what to say. The phone rang. It was Tori. (Again Mira's horizon: didn't know what to say). -Hello, Ben. Is it you? (Passing to the horizon of another character, Ben. The author does not intervene to clarify that Ben took the receptor and was listening to Tori etc.. etc.. So there is an immediate transition from Mira's horizon to that of Ben, although we are "in reality" and not in the consciousness of the character). - Well, - said Ben. (P1. in this case, only "said Ben"). Well, he is sweet-talking me, he thought. (It is obvious that the author's horizon appears only in "he thought"). Neta. Diri. Mariana. Not a word about Monda, she is different to him. He tastes her in loneliness. A cavalier relishes in solitude and keeps silent, repeated to himself a phrase overheard in a cafe. A dog too, he added after a little while "(Kadare I. 1973).
\end{abstract}

As seen from Mira's horizon, we move to the Ben's. The author appears to a minimum extend, "said Ben, he thought, he added," just to prove that we are on the horizon of his character. In "he sweet-talks ... Neta, Diri, Mariana, we are in the Interindividuality through /from Intersubjectivity. We can note again the climax here: cavalier / dog. In this case, the semantic point of view in, "cavalier" "dishonorates' in the word-group" relish in solitude ", which creates conditions for semantic association with" dog ", as a semantic intensification to serve as a climax.

We've seen how "in reality" the character's horizon dominates. We've also seen how, without the mediation of the author, it is passed from a character's horizon to the horizon of another one. We selected a chapter randomly, but could get any of them. The stylistic unit of the text has never been doubted in Kadare's prose / poetry. We are just considering, different chapters from different angles and point of views to approach the polyphonic text.

Conclusion: Even "in reality" dominates the character's horizon which comes directly from the Interindividuality through / from Intersubjectivity

The author's horizon is in a minimum extend, but when it appears, it appears to deny themselves, thus to help in its disappearance. In relation to Bakhtin polyphonic text, in Kadare's there is no author as "an orientation among the other orientations." This means that the author is not in a separate line in the polyphonic text nor has its own tone. Second, the "voices" in the polyphony of "The Winter" ... but not only, are just characters. Therefore, and tone of the text is polyphonic, heterogeneous. Above, we've seen the author's horizon in his alternation from "the reality" into the consciousness of the character, so in the function of marking the character's horizon. While, in the alternation of Consciousness / Reality, i.e. in the dominant in selfconscience, it is interesting to investigate stylistic choices which mark the exit to reality. More specifically, exits in reality are made from the character's horizon or of the author's?

We are always on. Chapter IV. We've seen how the transition is done from Mira's horizon to that of Ben. On p. 67, there is another transition through a dialogue from Ben's horizon, to the aunt's horizon: "Come on, come and have breakfast. Here's your egg. (Aunt, Rabo). Ben ate standing.Then he put on his jacket and left" (Kadare I.1973). It is noted that the author does not objectifies the sequence. So there is no: Ben sat down, took the plate etc... etc... That would be if we would have the author's horizon of the monological text. So we would have the "real" time. But, "Ben ate standing", etc., comes from Rabo's horizon. It's her who sees Ben eating and putting on his jacket and leaves. About this thing, there are only two sentences which are segmented because we are in Rabo's psychological time. This segmentation is a characteristic of Kadare's work, a segmentation that is conditioned by his creative schemes. And obviously that has nothing to do with segmentation, for example in Hemingway's prose. In two sentences it is mentioned what impresses Rabos, the way she sees and records in her memory, the fact that Ben "ate standing" and that he put on his jacket. In this case, the real-time is built by the reader, not the author. And here's what we have, later: "Ben got out":

"They left; she said to herself and sat down on the couch where Struga usually used to sit " (Kadare I.1973). We have: they left, said to herself - the author's horizon that comes to deny itself, which is obvious in where Struga usually used to sit. (Just as the aunt says to the brother.) So, we do not only have the stileme, "she said to herself" to make the transition from V, through the I, but also the marking of the object as it is seen by character. It follows:

"The refrigeration was making a monotonous babble.The book with memories of the war was on it. Recently, when she remained alone in the mornings, she put on the old glasses, opened the book and read a page here and there "(Kadare I.1973). 
At the "refrigerator ... we have still to do with the character's horizon, it is him who separates the refrigerator, the environment, the babble, and the book. The full scene is lacking precisely because we are in the Rabo's horizon. And the exit "in reality", "recently is made by Rabo's horizon and not by the author's, we are in her consciousness, in Intr. Below we are still in Intr: "It took her a long time to accept the thought that in a book's lines there can be extended past days, the killed people, different voices, war debris, streets with rain, thunder ". (Kadare I.1973). As it is always seen in Intr in "the lines of a book." The association / associations that metaphorize Kadare's prose come from there, thus from the character's world and from his horizon. And we have "thought that in a book's lines there can be extended past days, the killed people, different voices" etc. At the same time we have the increasing enumeration which ends with "thunder" and helps in producing the climax. Then we have a sequence of associations, as they come in Intr, always through the lines of a book, "To her it seemed that the lines of a book were like those of wool yarn and ... the wool before being spinned, it needed to be softened first, it was like maze" ...

It is the same metaphorization that comes from associations. Then, (but now maze): " That maze was full of whispers, thoughts, words, spleen and human spirit" ... You should make it to the end in these kind of associations, furthermore there are these associations which constrain the length of paragraphs: "Dead threads, dried, where events, villages, winters were squeezed "(Kadare I.1973). The other paragraph follows "in those endless lines ... the hope that between them she would find any familiar name" ... "There were there, two or three lines below and she almost wondered how they had not called her, had not made a sign since earlier "(Kadare I.1973).

We are therefore in Interindividuality through / by Intersubjectivity, which creates conditions that names in the book, in Rabo's consciousness become people.

In conclusion we can say that the author's horizon, that in Kadare's work comes out through the marking of the character in a given moment, it also appears to deny itself. This stylistic choice makes Kadare unique in relation to the characterization of polyphonic text in Bachtin, Alapat etc. Thus it appears that in Kadare's books we do not have the author as "an orientation among the other orientations." Thus, Kadare has sent the principle of polyphony to its peak. Which means that the author "disappears" in Kadare's work and it can be detected only in his creative scheme. This withdrawal of the author in his creative scheme is unique in the twentieth century fiction.

\section{References}

Bachtin. M, Dostojevskij, Poetica e stilistica Piccola biblioteca, Einaudi, Torino, 1968 fq. 74 Alapatt M F Polyphony and fiction. Shodhganga.inflibet.ac.in/bit.stream/10603/633/7/07/pdf Bachtin M. Dostojevskij... pg. 77

Bachtin M. Dostojevskij... pg. 78

Bachtin M. Dostojevskij... pg. 78

BachtinM.Dostojevskij...pg.78

Kadare I, Dimri i vetmisë së madhe Naim Frashëri Tiranë 1973. pg 57

Kadare I. Dimri i vetmisw sw madhe N. Frashwri 1973 pg 57

Kadare I. Dimri i vetmisw sw madhe N.Frashwri pg. 57

Kadare I. Dimri... pg. 58

Kadare I, Dimri... pg. 58

Kadare I. Dimri... pg. 58

Kadare I. Dimri... pg. 58

Kadare I Dimri... pg. 59

Kadare I. Dimri... pg. 59

Kadare I. Dimri...pg. 60

Kadare I. Dimri... pg.. 60

Kadare I. Dimri... pg. 60

Kadare I. Dimri... pg. 60 